\section{Flowering, Sex Expression, and Fruiting of Pumpkin (Cucurbita sp.) Cultivars under Various Temperatures in Greenhouse and Distant Field Trials}

\author{
H.C. Wien \\ Department of Horticulture, Cornell University, Ithaca, NY 14853 \\ S.C. Stapleton \\ University of Florida IFAS, North Florida Research and Education Center, \\ Live Oak, FL 32060 \\ D.N. Maynard \\ University of Florida IFAS, Gulf Coast Research and Education Center, \\ Bradenton, FL 34203 \\ C. McClurg \\ Department of Natural Resource Science and Landscape Architecture, \\ University of Maryland, College Park, MD 20742 \\ D. Riggs \\ D. Riggs Consulting, Stephenstown, NY 12168
}

Additional index words. Cucurbita pepo, Cucurbita maxima, sex expression, flower development

\begin{abstract}
Field production of decorative pumpkins (Cucurbita pepo L.) in New York occasionally results in markedly delayed fruit production in spite of normal vine growth. These episodes of fruitlessness appear to be associated with periods of high temperatures. To determine the link between temperature and pumpkin flowering and fruiting, a series of multilocational field trials and confirmatory greenhouse experiments were carried out. The field trials were conducted in the summer seasons of 1996 and 1997 in Ithaca and Albany, N.Y.; Queenstown, Md.; and Bradenton, Fla.; and in Ithaca and Bradenton in 1998. Mean growing season temperatures were $20,21,24$ and $28^{\circ} \mathrm{C}$, respectively, at the four locations in 1996 and 1997. Delay in fruit formation was indicated by the main stem node number at which the first fruit developed. In Ithaca and Albany, the six cultivars formed their first fruit at node 17, but fruit production shifted to node 24 at Queenstown, and to node 26 or more at Bradenton. The prolonged delay in fruiting at the warmest site resulted in a $74 \%$ decrease in total yield of the $C$. pepo cultivars in 1996 and 1997 , compared to Ithaca and Queenstown. In contrast, the yields and yield components of the C. maxima cultivar Prizewinner were similar at all four sites. Greenhouse trials in which 'Howden' and 'Baby Bear' were grown at 32/27, 25/20, and $20 / 15^{\circ} \mathrm{C}$ confirmed that high temperatures delay formation and anthesis of female flowers. This and other published work indicates that there are genetic differences in susceptibility to high temperature flower delay that could be exploited to improve pumpkin performance.
\end{abstract}

The commercial production of pumpkins in North America has traditionally been concentrated in the central and northern regions of the United States, and in southern Canada (Peirce, 1987). As market demand for decorative pumpkins during October and November has increased, more growers in southern states are attempting to produce the crop locally. Production problems of heavy disease and insect pressure, and "lack of adaptation" have resulted in low yields and discouraged local production in the southernmost states (Elmstrom et al., 1988). In cooler growing areas, such as upstate New York, female flower buds sometimes

Received for publication 26 Sept. 2002. Accepted for publication 17 Jan. 2003. turn yellow and then necrotic before anthesis after occasional hot spells (Wien and Riggs, personal observation). Although susceptible cultivars may not have any female flowers reach anthesis for more than a week in those conditions, there is no quantitative information on the effect of either short- or long-term high temperatures on pumpkin fruit production under field conditions.

Failure of cucurbit plants to form female flowers has been documented most extensively in cucumbers, where environmental conditions can influence whether a male or female flower is formed from a common primordium (Cantliffe, 1981; Goffinet, 1990). In general, moderate temperature and high light intensity favored development of pistillate flowers in monoecious cucumbers. High temperatures, especially if combined with low light conditions, reduced female flower numbers (Cantliffe, 1981).

Other researchers have noted a delay in female flower production when C.pepo plants are grown at higher temperatures. Nitsch et al. (1952) found that 'Acorn' squash grown under controlled environmental conditions at $30^{\circ} \mathrm{C}$ mean temperature and 16 -h photoperiod produced up to 160 nodes without a single female flower. Reducing the temperature, particularly at night, allowed female flowers to form at nodes 20 to 30 on the main stem. Similarly, NeSmith et al. (1994) observed that some zucchini cultivars produced fewer pistillate flowers when planted in midsummer in Georgia, when temperatures averaged $26^{\circ} \mathrm{C}$.

The objectives of the present study were to observe the temperature response of pumpkin flower sex expression and to determine the effect of different growing season temperatures on flowering and fruit formation of several pumpkin cultivars in a series of greenhouse and multilocational field trials.

\section{Materials and Methods}

Four-location field trial. Six cultivars of pumpkin were grown at Ithaca and Albany, N.Y.; Queenstown, Md.; and Bradenton, Fla., which provided a range of growing season temperatures. Ithaca, Queenstown, and Bradenton were the sites in 1996; all four locations were used in 1997; and the trial was repeated in Ithaca and Bradenton in 1998. Cucurbita pepo cultivars were 'Howden', an open-pollinated, large-fruited (normally $10 \mathrm{~kg}$ ), viney cultivar; 'Wizard' and 'Appalachian', two hybrid lines with compact growth habit and moderate fruit size (6-8 kg); 'Rocket', an early-fruiting, viney hybrid with medium-large fruit; and 'Baby Bear', a small-fruited $(1 \mathrm{~kg})$ hybrid with extensive vines. The large-fruited (20-30 kg) 'Prizewinner' hybrid (C. maxima) was also included in the trials.

Seeds for all the trials were from commercial sources, and were from the same seed lots for trials at all locations. Seeds for all Ithaca trials were started in Todd Planter polystyrene trays in a greenhouse at Cornell set at $25 / 20^{\circ}$ $\mathrm{C}$ day/night temperature, and transplanted after $\approx 3$ weeks. The other plantings were direct-seeded in the field. Sowing and harvest dates were timed to have marketable fruit by mid-October at each location (Table 1). The 12-plant plots consisted of single rows $7.3 \mathrm{~m}$ long and $2.7 \mathrm{~m}$ apart, with plants $0.61 \mathrm{~m}$ apart in the row. The between-row spacing was $3 \mathrm{~m}$ in the Queenstown plantings. There were two replications in 1996, and four in 1997 and 1998. Levels of applied nitrogen were at or below state guidelines in each planting (Table 2). Local cultural practice recommendations for control of weeds, insects, and diseases were used at each site, and were adequate to assure normal crop growth in each location. Rainfall was supplemented by sprinkler irrigation at all locations except Bradenton, where seepage irrigation maintained the watertable of the beds. Temperature data were obtained from weather stations in the vicinity of the experimental sites. 
Table 1. Dates of sowing and harvest for six pumpkin cultivars grown in four locations from 1996 to 1998.

\begin{tabular}{|c|c|c|c|c|c|c|}
\hline \multirow[b]{2}{*}{ Location } & \multicolumn{3}{|c|}{ Dates of sowing } & \multicolumn{3}{|c|}{ Dates of harvest } \\
\hline & 1996 & 1997 & 1998 & 1996 & 1997 & 1998 \\
\hline Ithaca, N.Y. & 24 May & 19 May & 24 May & 21 Sept. & 29 Sept. & 23 Sept. \\
\hline Albany, N.Y. & --- & 10 June & --- & --- & 24 Sept. & --- \\
\hline Queenstown, Md. & 6 June & 6 June & --- & 23 Sept. & 22 Sept. & --- \\
\hline Bradenton, Fla. & 16 July & 28 July & 28 July & 3 Oct. & 23 Oct. & 16 Oct. \\
\hline
\end{tabular}

Table 2. Soil types, nitrogen fertilizer rates, and previous crops grown in the experimental fields for pumpkin trials conducted in four locations from 1996 to 1998.

\begin{tabular}{lclccl}
\hline Location & Year & \multicolumn{1}{c}{ Soil type } & $\mathrm{N}$ rate $\left(\mathrm{kg} \cdot \mathrm{ha}^{-1}\right)$ & Nitrate $(\%)$ & Previous crop \\
\hline Ithaca & 1996 & Arkport sandy loam & 112 & 78 & Sweet corn \\
& 1997 & Arkport sandy loam & 103 & 78 & Cucurbits \\
& 1998 & Howard gravelly loam & 103 & 78 & Dry beans \\
Albany & 1997 & Teel silt loam & 56 & 20 & Field corn \\
Queenstown & 1996 & Mattapeake silt loam & 92 & 84 & General vegetables \\
& 1997 & Mattapeake silt loam & 87 & 84 & General vegetables \\
Bradenton & 1996 & Eau Gallie fine sand & 168 & 72 & Fallow \\
& 1997 & Eau Gallie fine sand & 168 & 72 & Fallow \\
& 1998 & Eau Gallie fine sand & 168 & 72 & Fallow \\
\hline
\end{tabular}

When the first fruits had reached a diameter of at least $10 \mathrm{~cm}$ on the large-fruited cultivars, the location of the first-formed fruits on the main stem was noted on six plants randomly chosen within each plot. Yields were obtained by harvesting all the plants, tracing vines into adjacent plots if necessary, and weighing and counting all fruits. The harvest sample included unmarketable fruits, but not immature fruits that were green and less than typical marketable size for the cultivar.

Statistical analysis of the data was conducted with MSTAT software (Michigan State Univ., East Lansing). Data were analyzed separately for each year with locations and cultivars as factors.

Greenhouse experiment. To determine the effect of temperature on development of female flower primordia under more controlled conditions than are available in the field, 'Howden' and 'Baby Bear' were grown in three greenhouse compartments. Seeds for the temperature experiments were germinated at $32 / 27^{\circ} \mathrm{C}$ (day/night) in moist paper towels and normal, vigorous seedlings selected after $3 \mathrm{~d}$ and transplanted into $23-\mathrm{cm}$-diameter (7-L volume) pots filled with peat-vermiculite artificial soil mix. Ten pots per treatment were placed in greenhouse compartments set at 32/27, 25/20, and $20 / 15^{\circ} \mathrm{C}$. Pots were spaced $100 \mathrm{~cm} \times 46$ $\mathrm{cm}$ on the bench and vines trained to the bench middles. Because of differences in vine vigor, 'Howden' and 'Baby Bear' were placed in adjacent blocks on the same bench. Natural light was supplemented by light from metal halide lamps for a 12-h duration during the day, to provide at least $325-400 \mu \mathrm{mol} \cdot \mathrm{cm}^{-2} \cdot \mathrm{s}^{-1}$ irradiance. Location of male and female flower buds on the main stem was noted at weekly intervals when first visible. Plants continued to grow and develop flowers due to lack of pollination and fruit set in the greenhouse (El Keblawy and Lovett-Doust, 1996). The experiment was conducted twice, beginning in Nov. 2001 and Feb. 2002, in natural photoperiods that ranged from 11.5 to $15 \mathrm{~h}$. Since the data obtained were similar in both iterations, means and standard errors were calculated on the pooled 20 plants per treatment.

\section{Results}

Four-location field trial. The field experiments were conducted to determine if female flower inhibition would occur under field conditions of high temperature. Weather records from all locations indicated that temperatures were different (Table 3), both during the entire growing season, and during the 21- to 51-d period when female flowers were presumably developing. At Bradenton, maximum temperatures exceeded $30{ }^{\circ} \mathrm{C}$ daily during days $21-51$, and commonly in the rest of the season. This frequency was half or less in the other locations.

A one-time inspection of the location of first-formed fruit on the main stem of the plants at the four locations served as an indication of

Table 3. Growing season average temperatures and days with maximum temperature above $30^{\circ} \mathrm{C}$, for four field locations in 1996 to 1998.

\begin{tabular}{|c|c|c|c|c|c|c|c|c|c|c|c|c|}
\hline \multirow[b]{3}{*}{ Location } & \multicolumn{6}{|c|}{ Avg temp $\left({ }^{\circ} \mathrm{C}\right)$} & \multicolumn{6}{|c|}{ Days with max temp $>30^{\circ} \mathrm{C}$} \\
\hline & \multicolumn{3}{|c|}{ Days 21-51 } & \multicolumn{3}{|c|}{ Entire season } & \multicolumn{3}{|c|}{ Days $21-51$} & \multicolumn{3}{|c|}{ Entire season } \\
\hline & $\overline{1996}$ & 1997 & 1998 & 1996 & 1997 & 1998 & $\overline{1996}$ & 1997 & 1998 & 1996 & 1997 & 1998 \\
\hline Ithaca & 19.2 & 18.2 & 20.4 & 20.0 & 19.2 & 20.6 & 1 & 2 & 1 & 2 & 8 & 4 \\
\hline Albany & --- & 21.6 & --- & --- & 20.2 & --- & --- & 7 & --- & -- & 21 & --- \\
\hline Queenstown & 24.2 & 25.4 & --- & 23.9 & 24.0 & --- & 14 & 14 & --- & 42 & 34 & --- \\
\hline Bradenton & 27.2 & 27.3 & 28.3 & 27.8 & 27.0 & 28.0 & 30 & 30 & 30 & 77 & 81 & 77 \\
\hline
\end{tabular}

Table 4. Node of first fruit on the main stem of six pumpkin cultivars grown in four locations, 1996 to 1998. Statistical analysis was conducted separately for each year, with locations and cultivars as factors.

\begin{tabular}{|c|c|c|c|c|c|c|c|c|c|}
\hline \multirow[b]{2}{*}{ Location $^{2}$} & \multicolumn{3}{|c|}{1996} & \multicolumn{4}{|c|}{1997} & \multicolumn{2}{|c|}{1998} \\
\hline & $\overline{1}$ & 3 & 4 & 1 & 2 & 3 & 4 & 1 & 4 \\
\hline Cultivar & \multicolumn{9}{|c|}{ No to first fruit } \\
\hline Howden & 24 & 30 & 28 & 23 & 22 & 29 & $30^{y}$ & 21 & 33 \\
\hline Wizard & 16 & 24 & $24^{y}$ & 16 & 16 & 18 & 23 & 15 & 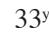 \\
\hline Rocket & 17 & 20 & 30 & 17 & 17 & 22 & 27 & 16 & 34 \\
\hline Baby Bear & 17 & 27 & 28 & 16 & 16 & 22 & 28 & 17 & 38 \\
\hline Appalachian & 15 & 26 & 24 & 15 & 14 & 18 & 18 & 14 & $30^{y}$ \\
\hline Prizewinner & 23 & $28^{y}$ & 27 & 18 & 18 & 24 & 24 & 21 & 36 \\
\hline Mean & 19 & 26 & 27 & 18 & 17 & 22 & 25 & 17 & 34 \\
\hline Statistical significance & \multicolumn{3}{|c|}{1996} & \multicolumn{4}{|c|}{1997} & \multicolumn{2}{|c|}{1998} \\
\hline$\overline{\text { Location }(\mathrm{L})}$ & \multicolumn{3}{|c|}{$* * *$} & \multicolumn{4}{|c|}{$* * *$} & \multicolumn{2}{|c|}{ *** } \\
\hline Cultivar (C) & \multirow{2}{*}{\multicolumn{3}{|c|}{$\begin{array}{c}* * * \\
\text { NS }\end{array}$}} & \multirow{2}{*}{\multicolumn{4}{|c|}{$\begin{array}{l}* * * * \\
* *\end{array}$}} & & \\
\hline $\mathrm{L} \times \mathrm{C}$ & & & & & & & & \multicolumn{2}{|c|}{ NS } \\
\hline $\mathrm{SE}$ & \multicolumn{3}{|c|}{2.76} & \multicolumn{4}{|c|}{2.35} & \multicolumn{2}{|c|}{3.42} \\
\hline $\mathrm{CV}$ & \multicolumn{3}{|c|}{10.3} & \multicolumn{4}{|c|}{10.8} & \multicolumn{2}{|c|}{14.1} \\
\hline
\end{tabular}

${ }^{2}$ Trial locations: 1 = Ithaca, N.Y.; 2 = Albany, N.Y., 3 = Queenstown, Md.; 4 = Bradenton, Fla.

${ }^{y}$ Fewer than half the plants sampled had main stem fruits. Only plants with fruits on the main stem were used to calculate the average.

Ns, $, * * *, * * *$ Nonsignificant or significant at $P \leq 0.05,0.01$, or 0.001 , respectively. 
Table 5. Yield per plant and yield components of six pumpkin cultivars grown at several locations during 1996 to 1998 .

\begin{tabular}{|c|c|c|c|c|c|c|c|c|c|}
\hline \multirow[b]{2}{*}{ Location $^{2}$} & \multicolumn{3}{|c|}{1996} & \multicolumn{4}{|c|}{1997} & \multicolumn{2}{|c|}{1998} \\
\hline & 1 & 3 & 4 & 1 & 2 & 3 & 4 & 1 & 4 \\
\hline & & & & $---Y$ & d per & $\mathrm{tt}(\mathrm{kg})$ & & & --- \\
\hline Howden & 12.6 & 7.5 & 1.5 & 9.3 & 11.8 & 12.6 & 1.7 & 8.2 & 1.1 \\
\hline Wizard & 10.0 & 7.3 & 2.1 & 9.0 & 7.4 & 8.2 & 2.0 & 7.3 & 1.9 \\
\hline Rocket & 14.4 & 10.9 & 6.8 & 12.5 & 11.4 & 15.0 & 2.3 & 7.8 & 3.9 \\
\hline Baby Bear & 6.6 & 3.9 & 1.1 & 5.4 & 3.8 & 7.0 & 2.5 & 4.3 & 0.4 \\
\hline Appalachian & 11.7 & 9.0 & 5.9 & 13.1 & 10.2 & 22.1 & 1.4 & 6.8 & 2.8 \\
\hline \multirow[t]{2}{*}{ Prizewinner } & 18.4 & 18.5 & 16.7 & $3.1^{\mathrm{y}}$ & 14.1 & 20.1 & 6.5 & 12.9 & 10.3 \\
\hline & & & & $-\mathrm{H}$ & it no. & plant & & & - \\
\hline Howden & 1.2 & 1.0 & 0.3 & 1.0 & 1.4 & 1.6 & 0.5 & 1.0 & 0.4 \\
\hline Wizard & 1.6 & 1.5 & 0.8 & 1.6 & 1.6 & 1.6 & 0.9 & 1.2 & 0.7 \\
\hline Rocket & 2.0 & 2.3 & 1.6 & 2.0 & 1.9 & 2.9 & 1.0 & 1.5 & 1.4 \\
\hline Baby Bear & 8.3 & 6.1 & 2.0 & 7.1 & 5.1 & 9.4 & 4.9 & 5.8 & 1.0 \\
\hline Appalachian & 1.5 & 1.6 & 1.0 & 1.7 & 1.5 & 2.8 & 0.6 & 1.2 & 0.8 \\
\hline \multirow[t]{2}{*}{ Prizewinner } & 0.9 & 0.8 & 0.9 & $0.3^{y}$ & 0.8 & 0.9 & 0.5 & 0.9 & 0.8 \\
\hline & -- & & & & t per $f$ & $\mathrm{~kg}$ ) & & & ---- \\
\hline Howden & 10.9 & 8.1 & 4.1 & 9.9 & 8.6 & 8.0 & 3.7 & 8.2 & 2.4 \\
\hline Wizard & 6.2 & 4.8 & 2.6 & 5.6 & 4.7 & 5.2 & 2.1 & 6.2 & 2.2 \\
\hline Rocket & 6.4 & 4.7 & 4.2 & 6.4 & 5.9 & 5.2 & 2.2 & 5.0 & 2.8 \\
\hline Baby Bear & 0.8 & 0.6 & 0.5 & 0.7 & 0.7 & 0.7 & 0.5 & 0.7 & 0.4 \\
\hline Appalachian & 7.8 & 5.6 & 5.7 & 7.6 & 6.7 & 7.8 & 2.6 & 5.9 & 3.6 \\
\hline Prizewinner & 21.0 & 24.0 & 19.0 & $7.8^{y}$ & 18.9 & 22.1 & 12.6 & 13.8 & 12.3 \\
\hline
\end{tabular}

${ }^{2}$ Trial locations: 1 = Ithaca, N.Y.; 2 = Albany, N.Y.; 3 = Queenstown, Md.; 4 = Bradenton, Fla.

y'Prizewinner' at Ithaca planted 3 weeks late in 1997.

time of fruiting. These observations show that a delay in fruit setting occurred at Bradenton, and to a lesser extent, at Queenstown (Table 4). First fruit were found at nodes 17 to 19 for the two New York sites, but were displaced to node 25 or more at Bradenton. In all 3 years at Bradenton, a majority of plants sampled in one or more cultivars bore no fruits on the main stem at all. Only rarely could fruits be found on branches on these plants (data not shown); the plants were commonly barren. Fruits were found at intermediate main stem nodes in the Queenstown plantings compared to the New York locations (Table 4). With the delay in fruit production at Queenstown and Bradenton, the plants continued to produce additional main stem nodes, so at the time of sampling, plants had $36 \pm 4$ and $39 \pm 5$ nodes, respectively, compared to $33 \pm 4$ at the New York locations.

There were marked cultivar differences in fruit location on the main stem (Table 4). 'Appalachian', 'Prizewinner', 'Howden', and 'Wizard' were less variable in location of the first fruit among locations than 'Baby Bear' and 'Rocket', leading to a significant location $\times$ cultivar interaction in 1997. At Bradenton, 'Howden', 'Wizard', and 'Baby Bear' were most frequently devoid of main stem fruits, indicating that these cultivars are particularly prone to delays in flower development.

The fruit yield per plant was significantly lower at Bradenton than at the other locations in all years (Tables 5, 6). As expected, cultivar differences were marked, with the small-fruited 'Baby Bear' producing lower yields than the large-fruited lines. 'Prizewinner' was the highest-yielding cultivar at every location (except Ithaca in 1997, when a sowing error caused a 3 -week delay in planting of this cultivar).

Yield decreases at Bradenton compared to other locations were caused both by fewer fruits per plant and significantly smaller fruit size than at the other locations (Tables 5, 6).
Fruit numbers were decreased to the greatest extent with 'Howden', 'Wizard', and 'Baby Bear', the same cultivars that were most often barren (Table 4). 'Prizewinner', on the other hand, maintained similar fruit numbers per plant at all locations.

When first fruit were displaced to higher nodes on the main stem at Bradenton, the fruit that eventually formed were smaller in size than at the cooler locations (Table 5). This is especially true for 'Howden' , 'Wizard', 'Rocket', and 'Appalachian' in 1997 and 1998. Although 'Baby Bear' also had fewer fruits, in Table 5.

respectively.

${ }^{\mathrm{z}}$ Fewer than half the plants had open flowers. fruit size was reduced to a lesser extent. 'Prizewinner' had the smallest fruit size reduction at Bradenton compared to mean fruit weight at the other sites. The interaction of location and cultivar was highly significant in all 3 years (Table 6).

Greenhouse trial: When 'Howden' was exposed to high air temperatures $\left(32 / 27{ }^{\circ} \mathrm{C}\right.$ day/night), the first female primordia were found at node 15 , but first open flowers only appeared at node 30 , and only on a few plants (Table 7). As in the field trials in Bradenton, many plants had no open female flowers. There was an overall reduction in female flower buds at the highest temperature. 'Baby Bear' showed similar but less dramatic trends than 'Howden', but all plants had open female flowers at $32 / 27^{\circ} \mathrm{C}$.

\section{Discussion}

Yield per plant of the C.pepo cultivars were 74\% lower at Bradenton in 1996 and 1997 than at Ithaca and Queenstown (Table 5). Similarly, in 1998 the yield at Bradenton was only $29 \%$ of that in Ithaca, due to a $66 \%$ smaller fruit size, and $60 \%$ fewer fruits per plant. The primary reason for this decline is likely the delayed formation of female flowers and their development to anthesis. Other factors, discussed below, may also have played a part.

It is possible that the low yields at Bradenton could also have resulted from a lack of fruit set under the warm conditions. Although the effect of high temperatures on fruit set has not been investigated in pumpkin cultivars, research on summer squash indicates that pollen development at $30^{\circ} \mathrm{C}$ compared to $20^{\circ} \mathrm{C}$ did not adversely affect pollen viability or seed numbers (Johannsson and Stephenson, 1998).

Table 6. Statistical analysis of yield and yield components shown

\begin{tabular}{llccc}
\hline Parameter & \multicolumn{1}{c}{ Factor } & 1996 & 1997 & 1998 \\
\hline Yield per plant (kg) & Location (L) & $*$ & $* * *$ & $* * *$ \\
& Cultivar (C) & $* * *$ & $* * *$ & $* * *$ \\
& L $\times$ C & NS & $* * *$ & NS \\
& SE & 3.9 & 2.7 & 1.6 \\
& CV (\%) & 28.0 & 29.4 & 32.3 \\
Fruit no. per plant & Location & $* *$ & $* * *$ & $* * *$ \\
& Cultivar & $* * *$ & $* * *$ & $* * *$ \\
& L $\times$ C & $* * *$ & $* * *$ & $* * *$ \\
& SE & 0.8 & 0.8 & 0.3 \\
& CV (\%) & 35.0 & 39.8 & 28.8 \\
Wt per fruit (kg) & Location & $* * *$ & $* * *$ & $* * *$ \\
& Cultivar & $* * *$ & $* * *$ & $* * *$ \\
& L $\times$ C & $* *$ & $* * *$ & $* * *$ \\
& SE & 1.1 & 2.1 & 0.8 \\
& CV (\%) & 14.8 & 35.6 & 16.2 \\
\hline Ns, *,***** Nonsignificant & or significant at $P \leq 0.05,0.01$, or 0.001,
\end{tabular}

Table 7. Response of two pumpkin cultivars to air temperature with regard to female flower development. Pooled means (standard errors) for 10 plants per treatment for each of two greenhouse plantings.

\begin{tabular}{|c|c|c|c|c|c|c|}
\hline \multirow[b]{2}{*}{ Air temp $\left({ }^{\circ} \mathrm{C}\right)$} & \multicolumn{2}{|c|}{$\begin{array}{c}\text { Node of 1st } \\
\text { female flower bud }\end{array}$} & \multicolumn{2}{|c|}{$\begin{array}{c}\text { Node of 1st } \\
\text { female flower }\end{array}$} & \multicolumn{2}{|c|}{$\begin{array}{c}\text { Nodes with } \\
\text { female buds }(\%)\end{array}$} \\
\hline & Howden & Baby Bear & Howden & Baby Bear & Howden & Baby Bear \\
\hline $20 / 15$ & $10(1.6)$ & $7.8(1.0)$ & $9.9(1.7)$ & $7.8(1.0)$ & $17.7(4.1)$ & $25.4(3.7)$ \\
\hline $25 / 20$ & $10.8(2.3)$ & $9.8(1.2)$ & $11.6(1.9)^{\mathrm{z}}$ & $10.0(1.6)$ & $17.0(3.8)$ & $21.6(3.7)$ \\
\hline $32 / 27$ & $15.4(4.5)$ & $14.8(4.0)$ & $29.5(4.9)^{z}$ & $17.4(6.8)$ & $12.2(3.8)$ & $16.1(3.3)$ \\
\hline
\end{tabular}


It has not been reported if ovaries developed to anthesis at elevated temperatures are functional, and if fruit set is possible under those conditions. Successful fruit production in hot weather may thus have additional obstacles to overcome.

It is unlikely that environmental factors other than high temperature had a major influence on the delay of female flowers at Bradenton. Daily irradiance levels were within $6 \%$ of levels in Ithaca in 1998, and daylengths were $\approx 2 \frac{1}{2} \mathrm{~h}$ shorter in Bradenton than in Ithaca. The controlled environmental studies of Nitsch et al. (1952) indicate that short photoperiods foster female flower development, the opposite to the effect obtained here.

Differences among locations in disease and insect pest incidence, predation by animals, fertility conditions, etc., could of course also have played a role in the location differences in performance, except that good cultural practices were used, and plant growth, as indicated by node development (Table 4) was highest at the warmest location. Nitrogen rates used were appropriate and not excessive at the four locations, considering the soil types on which the trials were conducted, and the previous crops on those plots (Table 2).

The greenhouse experiment confirms that differentiation of female flower primordia can be displaced to higher nodes at $32 / 27^{\circ} \mathrm{C}$ (Table 7 ), and that the first-formed female buds do not develop to anthesis. Male flower production did not appear to be adversely affected at the high temperatures in the greenhouse nor at Bradenton.

Although the results indicated some cultivar differences in reaction to the elevated tempera- tures of Florida, the $C$. pepo cultivars used were all somewhat adversely affected. There are indications that other researchers have found a greater range of heat tolerance in this species. NeSmith et al. (1994) indicated some differences among summer squash cultivars in ability to produce female flowers under high temperature conditions in Georgia. Alternatively, the results with the cultivar Prizewinner indicate that $C$. maxima may be tolerant of high temperatures. This is unlikely to be true for all cultivars in the species, however, since Sutherland and Bull (1985) have reported that an Australian cultivar of C. maxima produced few female flowers to anthesis when grown in high temperatures at sea level in Papua New Guinea.

Fruit development without pollination has been reported in C. pepo (summer squash), but appears to be suppressed at temperatures of 20 ${ }^{\circ} \mathrm{C}$ and above (Robinson and Reiners, 1999; Rylski, 1974). Selection of lines with increased parthenocarpic tendency is thus not likely to be useful to improve high temperature fruit production in pumpkin.

In summary, our results indicate that high temperatures prevailing in the southeastern United States during the summer months could significantly delay the formation of pumpkin fruits on many current cultivars. In the warmest locations, this delay may prevent sufficient fruit production in time for the fall market season. Although there are indications that genetic differences exist within C.pepo to improve female flower development capability under high temperatures, only the C. maxima cultivar Prizewinner showed adequate high temperature tolerance in these trials.

\section{Literature Cited}

Cantliffe, D.J. 1981. Alteration of sex expression in cucumber due to changes in temperature, light intensity and photoperiod. J. Amer. Soc. Hort. Sci. 106:133-136.

El Keblawy, A. and J. Lovett-Doust. 1996. Resource re-allocation following fruit removal in cucurbits: Patterns in two varieties of squash. New Phytol. 133:583-593.

Elmstrom, G.W., P.R. Gilreath and D.N. Maynard. 1988. Pumpkins: A potential commercial crop for Florida. Proc. Fla. State Hort. Soc. 101:382-385.

Goffinet, M.C. 1990. Comparative ontogeny of male and female flowers of Cucumis sativus, $\mathrm{p}$. 288-304. In: D.M. Bates and C. Jeffrey (eds.). Biology and utilization of the Cucurbitaceae. Cornell Univ. Press, Ithaca, N.Y.

Johannsson, M.H. and A.G. Stephenson. 1998. Effects of temperature during microsporogenesis on pollen performance in Cucurbita pepo L. (Cucurbitaceae). Intl. J. Plant Sci. 159:616-626.

NeSmith, D.S., G. Hoogenboom and D.W. Groff. 1994. Staminate and pistillate flower production of summer squash in response to planting date. HortScience 29:256-257.

Nitsch, J.P., E.B. Kurtz, Jr., J.L. Liverman, and F.W. Went. 1952. The development of sex expression in cucurbit flowers. Amer. J. Bot. 39:32-43.

Peirce, L.C. 1987. Vegetables: Characteristics, production and marketing. Wiley, New York. p. 374.

Robinson, R.W. and S. Reiners. 1999. Parthenocarpy in summer squash. HortScience 34:715-717.

Rylski, I. 1974. Effects of season on parthenocarpic and fertilized summer squash (Cucumis pepo L.). Expt. Agr. 10:39-44.

Sutherland, J.A. and P.B. Bull. 1985. Pollination and fruit set in two species of pumpkins in lowland Papua New Guinea. Papua New Guinea J. Agr. For. Fish. 33:143-147. 